http://nv.nltu.edu.ua

https://doi.org/10.15421/40270712

$@ \bowtie$ Correspondence author

Article received 25.08.2017 p.

Article accepted 28.09.2017 p.

K. O. Doroshkevych

УДК 658.012.32:658.589

\author{
kateryna.o.doroshkevych@lpnu.ua
}

К. О. Дорошкевич1, М. М. Вороновська ${ }^{1}$, I. З. Салата ${ }^{2}$

${ }^{1}$ Національний університет "Львівська політехніка", м. Львів, Украйна

${ }^{2}$ Національна академія сухопутних військ ім. гетьмана Петра Сагайдачного, м. Львів, Украйна

\title{
ЗАСТОСУВАННЯ МЕНТОРИНГУ ДЛЯ СТИМУЛЮВАННЯ ІННОВАЦІЙНОЇ ДІЯЛЬНОСТІ ПРАЦІВНИКІВ ПІДПРИЄМСТВ
}

\begin{abstract}
Окреслено можливість застосування менторингу для стимулювання інноваційної діяльності працівників підприємств у процесі її мотивування, спонукання працівників підприємства та його керівників на досягнення особистих цілей та цілей діяльності підприємства. Для цього поставлено та вирішено низку завдань: узагальнено визначення менторингу в управлінській діяльності на підприємстві як методу навчання та розвитку персоналу, під час якого більш досвідчений працівник (наставник, ментор) ділиться знаннями зі своїми колегами (менті) протягом певного часу; уточнено відмінність менторингу та коучінгу, яка полягає у тому, що у процесі менторингу вирішують складніші управлінські завдання та у можливості менторингової діяльності серед коучів; сформовано класифікаційні ознаки залежно від способу проведення, ознаки способу та мети здійснення менторингу, за напрямом та відповідні їм види менторингу; визначено переваги (персоналізоване навчання на робочих місцях, нематеріальне стимулювання, саморозвиток персоналу, можливість встановлення зворотного зв'язку) та недоліки (суб'єктивність, довготривалість, необхідність забезпечення відповідних організаційних умов тощо) менторингу інноваційної діяльності працівників підприємств.
\end{abstract}

Ключові слова: мотивування; інноваційний розвиток; наставництво; коучінг.

Вступ. Функція мотивування $є$ невід'ємною частиною управлінських процесів на підприємствах. Вона, як відомо, передбачає спонукання працівників підприємства та його керівників для досягнення особистих цілей та цілей підприємства (Kuzmin \& Melnyk, 2003). Однією із основних задач, які потрібно вирішити у процесі мотивування працівників підприємства $є$ побудова результативної системи стимулювання, для чого застосовують стимули діяльності працівників. Їх прийнято поділяти на матеріальні (заробітна плата, додаткові грошові виплати, премії і винагороди) та нематеріальні (просування за службовою ієрархією, престижність праці, визначення іiі результатів, похвала тощо).

Незважаючи не те, що інноваційна діяльність важлива для забезпечення конкурентоспроможності вітчизняних підприємств, вона перебуває на етапі розвитку, який упродовж 2010-2016 рр. характеризується такими тенденціями. Частка інноваційно активних підприємств становить менше $20 \%$ від загальної кількості промислових підприємств (у 2016 р. показник становить 17,3\%), фінансування інноваційної діяльності відбувається за рахунок власних коштів підприємств (97,2\% загального обсягу витрат на інновації у 2016 р. здійснені із цього джерела), більша частина інноваційних витрат підприємств спрямовані на придбання машин, об- ладнання та програмного забезпечення (у 2015 р. частка цих витрат становить $80,7 \%$ у структурі інноваційних витрат), внаслідок чого видів інноваційної діяльності переважають маркетингові та організаційні інновації (Derzhkomstat, 2016).

Матеріали та методи дослідження. У зазначених умовах зростає значення творчої діяльності працівників, важливість генерування креативних ідей, спонукання творчої активності, чим актуалізується значення нематеріального стимулювання працівників. У таких умовах стимулами діяльності працівників є обрання членства у наукових установах, участь у конференціях, можливість вільного обрання напряму наукових досліджень тощо (Karpun, 2008).

Із метою підвищення рівня управлінських процесів на підприємствах та пожвавлення інноваційної активності працівників потрібно приділити увагу розвитку сучасних методів стимулювання працівників.

Результати дослідження та їх обговорення. Як метод нематеріального стимулювання інноваційної діяльності працівників підприємств можна застосувати менторинг. Згідно з визначенням, наведеним у (Vishniakova, 1999), менторинг - це: 1) надання допомоги викладачам у період їх входження у трудову діяльність, що передбачає адаптацію до умов та оволодіння майстер-

\section{Інформація про авторів:}

Дорошкевич Катерина Олегівна, канд. екон. наук, доцент кафедри менеджменту і міжнародного підприємництва.

Email: kateryna.o.doroshkevych@lpnu.ua

Вороновська Марта Миколаївна, канд. екон. наук, ст. викладач кафедри менеджменту і міжнародного підприємництва.

Email: marta_tomych@ukr.net

Салата Irop Зеновійович, канд. екон. наук, ст. наук. співробітник. Email: igor.zen9@yandex.ua

Цитування за ДСтУ: Дорошкевич К. О., Вороновська М. М., Салата І. З. Застосування менторингу для стимулювання інноваційної діяльності працівників підприємств. Науковий вісник НЛтУ України. 2017. Вип. 27(7). С. 70-73.

Citation APA: Doroshkevych, K. O., Voronovska, M. M., \& Salata, I. Z. (2017). Applying of Mentoring in Stimulation of Innovative Activity of Enterprise's Staff. Scientific Bulletin of UNFU, 27(7), 70-73. https://doi.org/10.15421/40270712 
ністю; 2) сфера педагогічної діяльності, що здійснюється на безоплатній основі особами, які не мають педагогічної освіти 3 метою виконання освітянської та виховної функції. Цей термін походить від англійського слова "mentor", що перекладається як наставник, керівник, вихователь (Dakhno, 2011). При цьому у менторинговій діяльності особу наставника прийнято називати ментором, а його учня - менті. Дещо інакше визначення цієї категорії подано у (Meister \& Willyerd, 2010). Згідно з ним менторинг потрібно розглядати як процес взаємодії і взаємодопомоги між колегами, можливість відкриття нових аспектів методики викладання.

Оскільки, як зазначає I. І. Дахно, усі види діяльності можна розглядати із позицій бізнесу (підприємницької діяльності), то від педагогіки менторинг перейшов у сферу економічної активності. У літературі $є$ чимало публікацій, в яких менторинг розглядають як елемент корпоративного навчання, методи навчання і розвитку персоналу, моделі наставництва, соціальна системи владних відносин тощо (Nordberg \& Ladyzhetc, 2008; Faliakhov, 2016; Pashkovska, 2016). Аналізування останніх досліджень та публікацій за проблемою визначення сутності, видів, особливостей менторингу дає змогу зробити такі висновки. У сфері управління менторинг розглядають як один із методів навчання та розвитку персоналу, під час якого більш досвідчений працівник ділиться знаннями зі своїми колегами протягом певного часу (The Similarities and Differences, 2013). Як різновид наставницької діяльності або один із методів менторингу в економічній літературі часто згадують коучінг. Розглянемо це ретельніше.

Відмінність між коучінгом та менторингом полягає у способах забезпечення цього процесу, незважаючи на єдність мети та цілей такої діяльності. Менторинг здебільшого стосується допомоги, надання консультацій та розроблення моделей поведінки з боку старшого колеги (EMCC Ukraine, 2017). Завдання менторингу та коучінгу мають різний рівень складності. Особливістю менторингу є те, що він формує особисту прив'язаність та зацікавленість менті, підвищує його мотивацію до професійного зростання. Нерідко у результаті менторингу між його учасниками формуються тісні зв'язки та дружні стосунки. Також менторинг $є$ ефективним методом навчання обох сторін, а не лише менті, як це передбачено процесом коучінгу.

Також менторинг можна використовувати у практиці професійної діяльності коучів. Зокрема, менторинг як обов'язкова процедура передбачений для сертифікації коучів у Міжнародній Федерації Коучинга (ICF).

Як вид професійної діяльності менторинг на законних підставах здійснюється і в Україні. Свропейська Рада Менторства та Коучинга (СРМК) за ініціативи асоціації коучів із 2008 р. відкрила представництво в Україні. Вона існує для того, щоб просувати позитивний досвід і міжнародні стандарти, а також створювати гарантії надання якісних послуг 3 менторства і коучінгу в Європі та Україні зокрема (Mental skills, 2017).

Існують такі види менторингу:

- за способом проведення: індивідуальний (ментор взаємодіє із менті індивідуально), груповий (ментор взаємодіє із групою менті), колективний (група менторів взаємодіє із колективом підприємства, цей варіант $\epsilon$ прийнятний на великих підприємствах) (Yanshyna, 2013);
- за ознакою способу та мети здійснення: формальний (структурований менторинг, 3 домінуванням відносин керівник - підлеглий, передбачає обов'язкову участь), неформальний (передбачає відносини вільного вибору між ментором та менті, здійснюється спонтанно), напівформальний менторинг (містить риси обох видів) (Sundukova \& Vanykina, 2016);

- за напрямом: прямий (класичний, відповідно до якого наставницька діяльність виконується від вищих рівнів управління до нижчих) і зворотний, за якого ментором $\epsilon$ менеджер нижчого рівня управління, аніж його менті (Sundukova \& Vanykina, 2016).

На думку Т.О. Сундової, Г.В. Ваникіна, підвищений інтерес до менторингу та його популярність зумовлена такими чинниками: реструктуризаціями та скороченнями на підприємствах, що вплинули на нестабільне моральне становище та низький рівень довіри працівників до керівництва підприємством; підвищеною чутливістю керівництва до проблем у колективі; інноваційними процесами на підприємствах, що є складовою частиною його інноваційної діяльності; необхідністю дієвого планування; низьким рівнем мотивації організаційних змін на підприємстві, браком кваліфікованих працівників (Belousov, 2013). 3 огляду на це, менторинг дає змогу підвищити рівень мотивування на підприємстві та сприяти його інноваційному розвитку, що зумовлює актуальність його використання на підприємствах в умовах інноваційної діяльності.

3 цією метою менторинг на підприємстві потрібно здійснювати згідно 3 таким порядком: діагностика проблеми, формування плану роботи; спостереження за роботою менті; робота у співпраці; самостійна діяльність менті; професійне обговорення результатів та забезпечення зворотного зв'язку. Особливостями цього процесу $є$ те, що ментор не виконує роботу за менті, а тільки допомагає йому у вирішенні поставлених завдань. При цьому (на етапі спостереження за роботою менті, у процесі співпраці та під час обговорення) він може застосовувати такі методи пізнання, як емпатія, абстрагування, інтуїція, аналіз та синтез, індукція, формалізація тощо.

Обговорення отриманих результатів. Водночас менторинг, як форма стимулювання інноваційної діяльності працівників підприємств шляхом їх навчання та розвитку, має переваги на недоліки. Їх знання важливе для підвищення результативності менторингової діяльності на підприємствах та отримання очікуваних результатів мотиваційних процесів в умовах інноваційного розвитку.

Так, менторинг дає змогу забезпечити персоналізований метод навчання працівників, надати їм інструмент до саморозвитку, сприяти заохоченню до праці та зменшенню плинності кадрів тощо. Водночас недоліком $\epsilon$ те, що менторинг характеризується значною суб'єктивністю, процес його впровадження є довготривалим та вимагає забезпечення відповідних організаційних умов. Переваги та недоліки менторингової діяльності узагальнено в табл.

Висновки. Отже, менторингова діяльність призначена для вирішення проблем діяльності підприємства шляхом навчання одних працівників та нематеріального стимулювання інших. Ї̈̈ сутність можна визначити як метод навчання та розвитку персоналу, під час якого більш досвідчений працівник ділиться знаннями зі своїми колегами протягом певного часу. 
Табл. Переваги та недоліки менторингової діяльності в умовах інноваційного розвитку підприсмств

\begin{tabular}{|c|c|c|}
\hline $\begin{array}{l}\text { Форма } \\
\text { стиму- } \\
\text { лювання }\end{array}$ & Перевага & Недолік \\
\hline \multirow{6}{*}{ 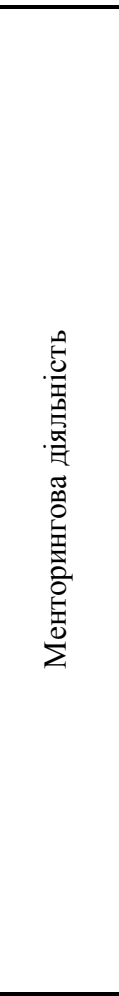 } & $\begin{array}{c}\text { Забезпечує навчання на } \\
\text { робочому місці }\end{array}$ & $\begin{array}{c}\text { Цикл впровадження менто- } \\
\text { рингу довготривалий та } \\
\text { становить понад } 1 \text { рік } \\
\end{array}$ \\
\hline & $\begin{array}{c}\text { Не потребує найму на } \\
\text { роботу, адже ментором } \\
\text { та менті } є \text { працівники } \\
\text { підприємства }\end{array}$ & $\begin{array}{c}\text { Для менті менторингова ді- } \\
\text { яльність } є \text { нематеріальним } \\
\text { стимулюванням, що порів- } \\
\text { няно із матеріальним, } є \\
\text { менш бажаним на вітчизня- } \\
\text { них підприємствах } \\
\end{array}$ \\
\hline & \begin{tabular}{|c} 
Забезпечує персоналі- \\
зований метод навчан- \\
ня працівників та \\
інструмент їх самороз- \\
витку \\
\end{tabular} & $\begin{array}{c}\text { Існують труднощі у виборі } \\
\text { ментора серед працівників } \\
\text { підприємства, який пови- } \\
\text { нен володіти експертними } \\
\text { знаннями } \\
\end{array}$ \\
\hline & $\begin{array}{c}\text { Забезпечує зворотний } \\
\text { зв'язок та вдосконален- } \\
\text { ня мотиваційних проце- } \\
\text { сів підприємства } \\
\end{array}$ & $\begin{array}{l}\text { Не існує чіткого порядку } \\
\text { менторингу та єдиного пе- } \\
\text { реліку рекомендованих } \\
\text { менторингових процедур }\end{array}$ \\
\hline & $\begin{array}{l}\text { У процесі менторингу } \\
\text { відбувається соціаліза- } \\
\text { ція груп працівників } \\
\text { різних національнос- } \\
\text { тей, віку, рівня освіти }\end{array}$ & $\begin{array}{l}\text { Для результативного впро- } \\
\text { вадження результатів мен- } \\
\text { торингу потрібно забезпе- } \\
\text { чити відповідний мораль- } \\
\text { но-психологічний клімат у } \\
\text { колективі } \\
\end{array}$ \\
\hline & $\begin{array}{c}\text { Зменшення плинності } \\
\text { кадрів унаслідок менто- } \\
\text { рингової діяльності }\end{array}$ & $\begin{array}{c}\text { Суб'єктивність менторин- } \\
\text { гової діяльності, що перед- } \\
\text { бачає вибір ментора та мен- } \\
\text { ті, визначення методів їх } \\
\text { співпраці, способів зворот- } \\
\text { ного зв'язку тощо } \\
\end{array}$ \\
\hline
\end{tabular}

Для досягнення цих цілей на підприємстві можуть бути застосовані формальний, неформальний, індивідуальний, груповий, колективний, зворотний менторинг тощо. Його використання має як переваги (персоналізоване навчання, нематеріальне стимулювання, саморозвиток персоналу), так і недоліки (суб'єктивність, довготривалість, необхідність забезпечення відповідних організаційних умов тощо) для підприємства.

У подальших дослідженнях потрібно визначити особливості менторингової діяльності для стимулювання працівників підприємств в умовах інноваційного розвитку.

\section{Перелік використаних джерел}

Belousov, M. (2013). Mentory ot informatcionnykh tekhnologii. Biznes-zhurnal, 4, 15-16. [in Russian].
Dakhno, I. I. (2011). Dilova kariera. Kyiv: Tsentr uchbovoi literatury. 528 p. [in Ukrainian].

Derzhkomstat (2016). Naukova ta innovatsiina diialnist $v$ Ukraini: stat. $z b$. Kyiv: Derzhkomstat. 256 p. Retrieved from: $\mathrm{http}: / /$ www.cisstat.com/innovation/Ukraine_publication_01.pdf. [in Ukrainian]

EMCC Ukraine (2017). Materialy Yevropeiskoi Rady Mentorstva ta Kouchynha (YeRMK). Retrieved from: http://www.emccouncil.org/ua/uk/

Faliakhov, I. I. (2016). Diversifikatciia modelei nastavnichestva mentor, tiutor, kouch, fasilitator i identifikatciia ikh gotovnosti $\mathrm{k}$ osushhestvleniiu nastavnicheskoi deiatelnosti. Kazanskii pedagogicheskii furnal, 2, 45-49. [in Russian].

ICF (n.d.) Chapter Bylaws. The International Coach Federation Russia Chapter. Retrieved from: http://www.icfrussia.ru/mezhdunarodnaya-sertifikatsiya-icf/mentoring-i-superviziya/

Karpun, I. N. (2008). Motyvuvannia i stymuliuvannia innovatsiinoi diialnosti pidpryiemstva. Visnyk Natsionalnoho universytetu "Lvivska politekhnika. Seriia: "Menedzhment ta pidpryiemnytstvo $v$ Ukraini: etapy vstanovlennia ta problemy rozvytku", 648, 529-533. [in Ukrainian].

Kuzmin, O. Ye., \& Melnyk, O. H. (2003). Osnovy menedzhmentu. Kyiv: Akademvydav. 416 p. [in Ukrainian].

Meister, J. C., \& Willyerd, K. (2010). The 2020 Workplace. How Innovative Companies Attract, Develop, and Keep Tomorrow's Employees Today. Harper Collins press.

Mental skills (2017). Nastavnychestvo (mentorstvo). Retrieved from: $\mathrm{http}: / /$ www.mental-skills.ru/dict/nastavnichestvo-mentorstvo/

Nordberg, L. V., \& Ladyzhetc, N. S. (2008). Mentoring kak sotcialnaia sistema vlastnykh otnoshenii. Vestnik Udmurtskogo universite$t a, 1,51-58$. [in Russian].

Pashkovska, T. (2016). Mentoring \& soaching: meta, perevahy, rezultaty. Yurydychna hazeta Online. Retrieved from: http:/yur-gazeta.com/publications/actual/mentoring--soaching-meta-perevagi-rezultati.html

Sundukova, T. O., \& Vanykina, G.V. (2016). Mentoring, edvaizing $i$ konsultirovanie kak innoytcionnye obrazovatelnye tekhnologii. Innovatcii $v$ obrazovatelnom prostranstve: opyt, problemy, perspektivy. Krasnoiarsk: Sibirskii federalnyi universitet. 217 p. [in Russian].

Similarities (2013). The Similarities and Differences between Coaching and Other Targeted Interventions Angelina Rosha, Information Systems Management Institute 2013/24 p. 119-126

Vishniakova, S. M. (1999). Professionalnoe obrazovanie. Slovar. Kliuchevye poniatiia, terminy, aktualnaia leksika.Moscow: NMTc SPO. [in Russian].

Yanshyna, T. (2013). Pidkhody do navchennia obdarovanykh ditei. Navchannia i vykhovannia obdarovanoi dytyny, 1, 322-329. [in Ukrainian].

К. О. Дорошкевич1, М. М. Вороновская1, И. 3. Салата

${ }^{1}$ Национальный университет "Львовская политехника", г. Львов, Украина ${ }^{2}$ Национальная академия сухопутных войск им. гетмана Петра Сагайдачного, г. Львов, Украина ДЕЯТЕЛЬНОСТИ РАБОТНИКОВ ПРЕДПРИЯТИЙ

Обозначены возможности применения менторинга для стимулирования инновационной деятельности работников предприятий в процессе ее мотивации (побуждения работников предприятия и его руководителей на достижение личных целей и целей деятельности предприятия). Для этого поставлены и решены ряд задач: обобщено определение менторинга в управленческой деятельности на предприятии как метода обучения и развития персонала, во время которого более опытный работник (наставник, ментор) делится знаниями со своими коллегами (менти) в течение определенного времени; уточнено отличие менторинга и коучинга, которое заключается в том, что в процессе менторинга решаются сложные управленческие задачи и в возможности менторинговой деятельности среди коучей; сформированы классификационные признаки в зависимости от способа проведения, признака способа и цели осуществления менторинга, в зависимости от направления и соответствующие им виды менторинга; определены преимущества (персонализированное обучение на рабочих местах, нематериальное стимулирование, саморазвитие персонала, возможность установления обратной связи) и недостатки (субъективность, долгая продолжительность, необходимость обеспечения соответствующих организационных условий и т.п.) менторинг инновационной деятельности работников предприятий.

Ключевые слова: мотивация; инновационное развитие; наставничество; коучинг. 
K. O. Doroshkevych ${ }^{1}$, M. M. Voronovska', I. Z. Salata ${ }^{2}$

${ }^{1}$ Lviv Polytechnic National University, Lviv, Ukraine

${ }^{2}$ Hetman Petro Sahaidachnyi National Army Academy, Lviv, Ukraine

\section{APPLYING OF MENTORING IN STIMULATION OF INNOVATIVE ACTIVITY OF ENTERPRISE'S STAFF}

The authors highlight the issue of activating mentoring activity at domestic enterprises to stimulate their innovation development. It is possible to create when applying mentoring to stimulate the innovative activity of employees in enterprises in the process of motivation, which induces enterprise's employees and its managers to achieve personal goals and objectives of the enterprise. Therefore, we applied the methods of theoretical generalization, systematization, analysis and synthesis, and scientific abstraction. As a result the following tasks are solved: the definition of mentoring in management activity on the enterprise as a method of training and development of the personnel is generalized, during which a more experienced employee (mentor) shares knowledge with his colleagues (mentee) for a certain time; the difference between mentoring and coaching is clarified, which means that in the process of mentoring more complex administrative tasks and the possibility of mentoring activity among coaches are solved; classification characteristics are formed depending on the way of conducting, the sign of the method and purpose of the implementation of the mentoring, in the direction and the corresponding types of mentoring; advantages (personalized training in the workplace, non-material incentives, self-development of staff, the possibility of establishing feedback) and disadvantages (subjectivity, long-term, the need to ensure appropriate organizational conditions, etc.) mentoring of innovation activities of enterprise employees are defined. To conclude, the authors prove the necessity to determine the features of mentoring activity the peculiarities of mentoring during the stimulation of employees of enterprises in conditions of innovative development in further research.

Keywords: motivation; innovation development; mentoring; coaching. 